\title{
LANGUAGE EDUCATION AND THE EVALUATING PRINCIPLE OF THE EXPRESSIVENESS OF SPEECH IN COMPLEX SENTENCE IN THE MARI LANGUAGE (THE CASE OF SYNTACTIC FIGURE OF THE PERIOD)
}

\author{
Galina L. Sokolova', Anna L. Kolyago ${ }^{2 *}$ \\ ${ }^{1}$ Assos. Prof., Mari State University, Russia, askgalinasokol@mail.ru \\ ${ }^{2}$ Assos. Prof., Mari State University, Russia, kolyago@yandex.ru \\ ${ }^{*}$ Corresponding Author
}

\begin{abstract}
Mastering the basics of language theory and language usage is one of the important components of language education. The purpose of language education is the formation of a language personality and the command of language competencies. Native language teaching is based on its own principles. One of the important principles is the principle of evaluating the expressiveness of speech, which implies, along with understanding the information function of language means, also understanding of the expressive (stylistic) function, understanding not only semantic, but also emotional shades and colors of words and turns of speech, metaphors and other tropes, and other means of artistic representation of the language.

The article considers the period as one of the effective stylistic figures of expressive syntax in complex sentence in the Mari language. Analysis of sources from the works of Mari fiction has shown that complex sentences in the Mari language have rich stylistic potential. In order to give the narrative imagery and expressiveness, solemnity and sublimity in the language of fiction, authors often use the syntactic figure of the period. The period is found in the Mari language in different types of complex sentences in writing. The sphere of use of the construction with the period is the language of works of fiction and journalism. The rhythm-forming function of the period, due to the protasis and apodosis of its parts, is inherent in Mari works of fiction. Journalistic speech with a period creates clarity of the narrative due to the lexical content, grammatical connection between the parts of the period. The period in journalism performs the function of generalization, contributes to the formulation of conclusions. The period is distinguished from other syntactic figures of speech by its emotional richness, lyricism, expressiveness and sublimity. The main distinguishing feature of the period is the presence of two parts: protasis and apodosis. Moreover, protasis is characterized by the presence of uniformity of components, repetitions and parallelism. One can find period in all types of complex sentences in the Mari language. However, it should be noted that the period in complex sentence in the Mari language is represented by fewer components than in Russian, as it is possible to use in Mari simple sentences, they follow each other to express a complex thought, and subordinate clauses can be replaced by adverbial-participial construction or participial construction, participle or adverbial participle, that are parts of simple expanded sentence without violating the meaning of the utterance.
\end{abstract}

Keywords: language education, principles of language education, Mari language, syntax, stylistics, complex sentence, expressivity, figures of speech, period 


\section{INTRODUCTION}

The Mari language has a relatively young written tradition. The written version of the Mari language appeared at the end of the XVIII century. Literary norms of the language began to develop after 1917. Until that time, the syntax of the Mari language was similar to that of the Finno-Ugric proto-language. It was characterized by the presence of one-part, two-part and nominal sentences. Expanded sentences were widely used in the speech. I. S. Galkin, like most researchers of the history of Finno-Ugric languages, notes that the Finno-Ugric proto-language did not have conjunctive complex sentences, they were successfully replaced by simple sentences following one another (Galkin, 2003). The development of complex sentences in the Mari language was influenced by the Russian language. This is confirmed by the presence of a large number of conjunctions in the Mari complex sentences. I. S. Galkin also notes the fact that today complex sentences of the Mari language often look like calque from the Russian language and can be easily replaced with sentences with adverbial-participial phrase (construction). Today's Mari language, being in close contact with the Russian language, has a rich and extensive system of complex sentences. They, in turn, make the language richer and more expressive.

Researchers of the Mari language dealing with syntax note the richness of its stylistic possibilities. The expressive possibilities of syntax have been studied by such researchers as L. A. Abukaeva, N. N. Glukhova, E. V. Volkova, I. G. Ivanova, A.V. Illarionov, N. M. Krasnova, and E. L. Yandakova. The stylistic potential of a complex sentence, syntactic figures of speech that give it imagery and expressiveness in the Mari language are described in detail in the dissertation research of N. N. Glukhova, L. A. Abukayeva and N. M. Krasnova.

In our research, we will continue to study the stylistic possibilities of a complex sentence (Sokolova, Kolyago $2019 \mathrm{a} ; 2019 \mathrm{~b} ; 2020)$ and devote the research to the period as one of the syntactic figures of speech.

\section{MATERIALS AND METHODS}

The relevance of the research is determined by insufficient knowledge of the problem of stylistic potential and expressiveness of the syntax of a complex sentence in the modern Mari language. The language of fiction books makes it possible to show the expressive possibilities of the syntactic figure of the period as part of complex sentences of different types.

The purpose of this study is to analyze the possibilities of using complex sentences with a period to give speech imagery, expressiveness, sublimity and solemnity.

In the study we use the structural-semantic method, the method of synchronous description and analysis of the collected material.

The task of the study is to analyze the expressive possibilities of the syntactic period in all its aspects in complex sentences in the language of fiction books in the Mari language.

The object of research is the stylistic possibilities of the syntactic figure of a period in a complex sentence.

The practical significance of the results is determined by the possibilities of their use in teaching the style and syntax of the Mari language.

\section{RESULTS}

In Russian, period refers to widely used stylistic figures of speech, both in simple and complex sentences. In the "Stylistic encyclopedia" of the Russian language, a period is defined as " ... a stylistic figure that represents a semantic and structural unity formed by a simple or complex sentence, as well as a complex syntactic whole, which are divided into two intonationally opposed parts - protasis, characterized by an increase, an upward movement of the tone, and apodosis, characterized by a decrease, a downward movement of the tone, and, from the point of view of content, representing the conclusion or consequence of what was said in the protasis " (Kuznetsova, http://endic.ru/stylistic/Period-6.html). A. A. Kuznetsova identifies the following features of periodic constructions: 1) structural closure; 2) binary (binomial) structure; 3) semantic-structural relationship and interdependence of parts; 4) contrasting intonation design of parts: increasing the tone in protasis and lowering in apodosis; 5 ) a long pause between protasis and apodosis; 6) structural and semantic parallelism of the members of the parts of the period (Kuznetsova, http://endic.ru/stylistic/Period-6.html).

Researchers of stylistic syntax think that the period is a component of book speech and gives it a character of increased expressiveness. K.A. Sat notes that a period is an element of structural syntax that "provides 
both logical and emotional imagery of speech" (Sat, 2010).

M. A. Kozik notes that the period is characterized by emotional intensity, lyrical or journalistic tension, harmony and musicality, and therefore is usually characterized by expressive speech, regardless of whether it is prose or poetic (Kozik, http://journals.altspu.ru/5-floor/article/view/557/510).

K. A. Sat, like many researchers of this syntactic figure, notes that the period provides "logical and emotional imagery of speech" (Sat, 2010). The researcher analyzes the research on the period in Russian linguistics and notes that there are four directions in the definition of the term period. K. A. Sat is of the opinion that the term period "expresses the essence of the syntactic and stylistic category" (Sat, 2010).

$\mathrm{N}$. I. Formanovskaya notes the constructive features of the period and refers to them "the uniformity of its parts, diverse repetitions, and structural parallelism" (Formanovskaya, 2015). However, despite the similarity of the period with the listed syntactic figures, according To N. I. Formanovskaya, "... it is clearly divided into two parts: the first one with an increase in tension in semantic, structural and prosodic components - an increase and the second one, which discharges the tension - a decrease" (Formanovskaya, 2015). Due to the decrease, the period is completed. The main features of the period are its structural, rhythmic-intonation, stylistic and expressive properties.

L. I. Baykova, who devoted her dissertation research to the period, examines it at the level of text linguistics. At the same time, she notes that "... by its nature, the period is a syntactic - stylistic phenomenon, since it has syntactic features" (Baykova, 2000). These include the use of a period within a sentence, the intonation division of parts of a period, the pause at the border of increases and decreases, and its rich stylistic potential.

\section{DISCUSSION}

The imagery and expressiveness of the syntactic figure of the period in the Russian language is an indisputable fact. There is no research on this syntactic figure in the Mari language. The categories of repetition and parallelism that accompany the syntactic figure of the period are well-studied phenomena of syntactic stylistics in the Mari language. The fact that the syntax of a complex sentence in the Mari language developed under the influence of the syntax of the Russian language suggests that the syntactic figure of the period is a means of expressiveness in the Mari language as well. This part of the study is devoted to the syntactic figure of a period in a complex sentence in different speech styles in the Mari language.

In the Mari language, we can find a period in a complex sentence in the written style of speech. The use of periodical constructions is typical for fiction and journalistic works. In the speech of fictionin and prose the period contributes to the creation of a special rhythm of utterance, for example: Йӱла пӧрт, йӱлат нылйолан изи пӧрт-влак; нуно кугу кайык йыр кышкыме кайыкигыла тулан шулыдырыштым лупшкедыл кият. 'Тhe house is on fire, the little houses on four legs are on fire: they lie like discarded chicks around the big birds and beat their burning wings' (V.Pacteau, 2018).

Батальон командир майор Мочалов инструктажым шке эртара: кузе нейтральный полосам эрташ, немыч тылыште кузе шкем кучаш, кузе немычым солалташ - радамын умылтара. 'The battalion commander, major Mochalov gives instructions: how to cross the neutral zone, how to behave in the rear of the Germans, how to take (grab) the Germans-he explains in order' (I. Ivanov, 2019).

Сержант кырт-корт кынел шогале, документым тергаш ошкыльо, а лейтенант тиде гана кӱлеш ыле палаткыш, ӱдыр-влак дек, шикшалте. 'The Sergeant barely got up, went to check the documents, and the Lieutenant this time it was necessary-disappeared in the tent of the girls' (I. Ivanov, Onchyko).

The language of poetry, thanks to the period, forms the information center of a lyric poem, for example:

Куэрлашет, вйд воктен,//Кайык муро йӱк шоктен,//Куэрлаште, вӱд воктен,//Ӱдыр качым ужатен... . 'In the grove, by the water,//you can hear the song of birds, // in the grove, by the water, / / the Girl saw off the guy...' (Kazakov, 2003).

Талгыде семын оржам рӱзалтен,//Курык мардеж кенета куржын тольо,//уйто айдемын мутланымым кольо://Рёп чарналтале мемнан йол воктен,//Талгыде семын оржам лап пыштен. 'Like a colt waving his mane, //the mountain wind came, //lt was like hearing a human voice://Suddenly stopped at our feet,//Like a colt with its mane down' (Kazakov, 2003).

Мый тугане мутым ойлынем,//Мый тугане семым кычалам, - //Шӱм гыч лектышт нуно иланен//Тачысе, эрласе кечылан. 'I want to say these words, / / I'm looking for such a motive, - //Let them come from my 
soul// To today, to tomorrow' (Kazakov, 2003).

Journalistic speech with a period creates a clear narrative due to the lexical content, grammatical connection between the parts of the period. The period in journalism serves as a generalization, contributes to the formulation of conclusions. To do this, the period is supplemented with the use of homogeneous parts, repetitions, and structural parallelism, for example:

А йылмын вийжым кӧ пенгыдемда, мер кӱкшытшым кӧ да кузе палдара, мер кӱлешлыкшым кӧ нӧлта, марий калыкын ынжым чын ончыктен моштымыжым кӧ эскера? 'And who will strengthen the power of the language, who will raise its social significance, who will monitor the ability of the Mari people to show themselves correctly?' (Solovyov, 2018 № 11).

Вот менмнан дене пырля илыше татар-влак мланде дек мелын шогат, мланде озанлыкым шот дене кучат, йылмыштым саклат, сыныштым аралат, арун чиемышт дене ойыртемалтыт, лӱмнерыштым аклат, шкеныштым шот дене кучат, шке калыкышт дене кугешнат, шке коклаште ваш келшен, ваш полшен илат. 'Living here next to us Tatars face turned to the earth, really are engaged in farming, preserve their language, their image, differ in clean clothes, appreciate his glory, behave sensibly, proud of their people, live together in harmony and help each other' (Solovyov, Onchyko 2018 № 12).

A period can be a part of all types of complex sentences. The period in complex sentence is expressed in the subordination and homogeneous subordinate part in relation to the main part of the sentence. The period is found in all types of subordinate clauses and is created by repetition and parallel constructions with conjunctions, pronouns, and identical lexical elements, for example:

Марий-влак угычын кугыжыныш кучем ваштареш («черемисские войны» манме сар семын) кынелын ынышт керт манын, нунылын апшат пашамат ышташ виеш чареныт, нуным олашке йӱдлан малашат пуртен огытыл - лӱдыныт. 'To prevent the Mari people from rebelling against the tsarist authority again (as in the so-called "Cheremis wars"), they were not allowed to practice blacksmithing, and they were not allowed to go to the cities at night - they were afraid' (Solovyov, Onchyko 2018).

Isolated and participial turns make subordinate clause with syntactic period compound, for example:

Кызыт ынде шуко марийже кок юмылан кумалеш: иктыже шўйышкыжӧ ыресым сакалта да кӱсотышко юмылам кумалеш, весыже юмона ончыко сортам чёктен шында да, сукен шинчын, Христос юмын але тудын аважын шинчашкыже ончен, чимарий чоклымо мутым вудымата. 'Now many Mari people pray to two gods: some hang a cross around their necks and pray in the sacred grove of Yuma, others light candles in front of icons and, kneeling, look into the eyes of Christ or the mother of God, muttering the words of pagan prayer' (Solovyov, Onchyko 2018).

Complex sentences also contain syntactic figures of the period, and, according to N. I. Formanovskaya, "... first, tension is built up in homogeneous constructed parts, and then, after a pause, a decrease follows" (Formanovskaya, 2015), for example:

Тудын кок кӱсенжат - эре оварыше. Ласка улмыж годым кидше пеш чӱчкыдынак кӱсеныш ок пуро, а, иктаж-могай амал дене шыде пуш лекмек, кидше тушто ялт овара - кӱсен кушкедла, шонет. 'Both his pockets are always swell. When he is calm, the hand does not often reach for the pocket, and if for some reason he is angry, the hand is straining there - the pocket will break, you think' (Ivanov, Onchyko 2019 № 9).

Conjunctionless complex sentences with a period are formed in the same way, for example:

Феодализмым, капитализмым илен эртышна, социализмыштат илен ончышна, коммунизмышкат изишак гына ышна шу - ышна йом вет.

'We survived feudalism and capitalism, tried to live in socialism, almost reached communism - we didn't get lost after all' (Solovyov, Onchyko 2018 № 12).

\section{CONCLUSION}

Following the principle of evaluating the expressiveness of speech involves primarily the use of fiction in language teaching, as well as other texts that clearly express the functional and stylistic features of the language. This material helps to understand the emotional and semantic subtleties of the text. Analysis of the syntactic figure of the period shows that this figure is found in the Mari language in different types of complex sentences in written speech. The sphere of use of the construction with the period is the language of fiction books and journalism. The rhythm-forming function of the period, due to the increase and decrease 
of its parts, is inherent in Mari fiction books. Journalistic speech with a period creates a clear narrative due to the lexical content, grammatical connection between the parts of the period. The period in journalism serves as a generalization, contributes to the formulation of conclusions. The period is distinguished from other syntactic figures of speech by its emotional intensity, lyricism, expressiveness, and sublimity. The main distinguishing feature of the period is its two-part nature, which is manifested in the presence of two parts: increase and decrease. Moreover, the increase is characterized by the presence of homogeneous of components. You can find period in all types of complex sentences in the Mari language. However, it should be noted that the period in complex sentence in Mari is represented by fewer components than in Russian. This feature is explained by the fact that to express complex though in the Mari language, it is possible to resort to simple sentences following each other, and subordinate clauses "...can be replaced by participial and adverbial-participial constructions or single participles and adverbial participles that are parts of a simple expanded sentence, without prejudice to the meaning of the utterance" (MML, 1961).

\section{ACKNOWLEDGEMENT}

This research was financially supported by RFBR and Government of the Mari El according to the research project No 19-412-120002 «Stylistic syntax of compound sentences in the Mari language»

\section{REFERENCE LIST}

Baykova, L.I. (2000). Period is a syntactic-stylistic and text-forming phenomenon of the Russian language. Thesis. http://cheloveknauka.com/period-sintaktiko-stilisticheskoe-i-tekstoobrazuyuschee-yavlenierusskogo-yazyka\#ixzz6H8dn5xHI

Galkin, I.S., Mustaev E.N. (2005). Финно-угроведенийын негызше. Морфологий, Синтаксис, Лексике. (р. 96). Mari State University. Yoshkar-Ola.

Ivanov, I.. (2019). Шарналте, лейтенант. (P. 9-65). Onychko Mari book publishing house. №.9

Kazakov, M. (2003). Йӧратыме поэзий йолташем. (р. 268). Yoshkar-Ola. Mari book publishing house.

Kozik, M.A. Period as a syntactic and stylistic technique. http:/journals.altspu.ru/5-floor/article/view/557/510

Kuznetsova, A.A. (2003). Stylistic encyclopedia of the Russian language. - M:. "Flint", "Science" Under the editorship of M. N. Kozhina http://endic.ru/stylistic/Period-6.html

Moren, M. K., Teterevnikova, N. N. (1960). Stylistics of the modern French language. (298 P). Publishing house of literature in foreign languages. Moscow.

Pekteev, V. (2018). Мӱкш тӱня гыч айдеме. (P. 63-95). Onychko Mari book publishing house. №. 1

Sat, K.A. (2010). Syntactic category of the period in the Russian philological tradition. Abstract of the dissertation for the degree of doctor of Philology. (p. 24). Moscow.

MML. (Modern Mari language). (1961). Syntax of a complex sentence. (152 P.) Mari publishing house. Yoshkar-Ola.

Sokolova, G.L., Kolyago, A.L. (2019 a). Complex Sentences in the Mari Language. Proceedings of ADVED 2019- 5th International Conference on Advances in Education and Social Sciences. (P. 291-294). Istanbul, Turkey.

Sokolova, G.L., Kolyago, A.L. (2019 в). Stylistic Features of the Compound Sentence in the Mari Language. Proceedings of ADVED 2019- 5th International Conference on Advances in Education and Social Sciences. ( P. 295-298). Istanbul, Turkey.

Sokolova, G.L., Kolyago, A.L. (2020). Expressive ways of reporting other persons' spreech in the Mari language. (P. 51-54). Proceedings of INTCESS 2020-7th International Conference on Education and Social Sciences. DUBAI (UAE).

Solovyov, V. (2018). Марий сын: ожно, кызыт, вара. (P. 104-115). Onychko. Mari publishing house. № 11. Solovyov, V. (2018). Мырий сын: Ожно, кызыт, вара. (P. 109-123). Onychko. Mari publishing house. № 12 Formanovskaya, N.I. (2015). Complex sentence: Semantic and stylistic aspects, 3rd ed. (240 p.). Moscow: LENAND 